\title{
The influence of experience and confidence on the health man- agement of dairy goat (Case study: "Simpay Tampomas Farmer Group" Village Cilengkrang, Cimalaka District of Sumedang, West Java-Indonesia)
}

\author{
Tyagita Hartady ${ }^{1,2, *}$, Rini Widyastuti ${ }^{2,3}$ \\ ${ }^{1}$ Department of Basic Biomedical Science, Division of Anatomy, Physiology and Cellular Biology, Faculty of \\ Medicine, Padjadjaran University, Indonesia \\ ${ }^{2}$ Veterinary Medicine Study Program, Faculty of Medicine, Universitas Padjajaran, Jatinangor, Indonesia \\ ${ }^{3}$ Laboratory of Animal Reproduction and Artificial Insemination, Departement of Animal Production, Animal \\ Husbandry Faculty, Universitas Padjajaran, Jatinangor
}

\begin{abstract}
Dairy goat is profitable object since the productivity is relatively brief, easy in maintenance and does not require much investment. Dairy goat become one of the important commodity for farmers in the village Cilengkrang, Cimalaka District of Sumedang. This study used a qualitative approach where 18 farmers who become interviewees. Collected data were observed and compared with the evaluation on the participants' routine. The majority farmers are depending on individual experiences and conclusions without related guidance and supported references of diseases and procedures in nurturing dairy goats $(61.1 \%)$, while the rest are consulting the problem to the vet or the group $(83,3 \%)$. Some of them used the conventional treatment. However, when the condition of sick animal never improved, only 83,3\% of farmers who contact veterinarian and the rest would prefer sell the animal in the market. It can be concluded that the majority farmers in the village, has experienced to overcome certain diseases of dairy goats. Nevertheless, the knowledge and sources of supporting references are still limited that affect to the use of inappropriate traditional herbs or regular human medicines from nearby stalls is still relatively high, so the awareness and knowledge of breeders about health management of dairy goat of breeders needs to be improved.

Keywords:

Experience and confidence, goat milk, Cimalaka, health management
\end{abstract}

\section{- INTRODUCTION}

Dairy goat farming is very profitable from the milk, meat, mohair, even its feces and urine. The goat productivity is relatively brief, easy in maintenance and does not require much investment. With all the promising potentials, dairy goat become one of the important commodity for farmers in the village Cilengkrang, Cimalaka District of Sumedang.

Almost $60 \%$ of the village population are farmers and breeders who are members of the Simpay Tampomas Farmer group with as many as 45 goats of Peranakan Ettawa population (Haq et al., 2016). However, farming is a side job and the goats are traditionally maintained and serves as an asset that can be sold whenever an urgent need (Yunita et al., 2017). The use of livestock technology has not been maximized, especially in increasing the production or population of livestock. The care and decision-making are shared among members in the family. Most farmers will rely on senior experiences while managing sick animals. Thus will certainly define how much confidence of a breed- ers in determining the best treatment for their livestock (Widyastuti et al. 2017).

Through the study, we expect there will be explanations of how experience and confidence influence the health management of dairy goat in village Cilengkrang, Cimalaka district of Sumedang, West Java-Indonesia. The obtained information has provided clue about the community manage goats health problems so the disease might be prevented in an appropriate manner.

\section{- OBJECT AND METHOD}

Object of study: The subject of this research is the member of Simpay Tampomas Farmer's group in village Cilengkrang, Cimalaka district of Sumedang, West Java-

Diterima: 21-05-2018 | Direvisi: 30-06-2018 | Disetujui: 12-07-2018 (C) 2018 CC-BY-SA. Ini adalah artikel Open Access yang didistribusikan berdasarkan ketentuan dari Creative Commons Attribution ShareAlike 4.0 International License (https://creativecommons.org/licenses/by-sa/4.0/). 
Indonesia, and the object is the role of experience to the capability of the breeder in dairy goat health management. Method: The study used a qualitative approach, included 18 farmers, both men and women, who became interviewees. Specific questions were directed and grouped according to the category that fit the research topic. The data of the research were analyzed by grouping the data based on the answer given by the interviewees. The accuracy of the data can be seen from the relevance of the interview result with the evaluation on the interviewees routine. If there is consistency and conformity between the information and the application, then the data and information given were considered accurate.

\section{- RESULT AND DISCUSSION}

It has been stated that $94,4 \%$ farmers of Village Cilengkrang, Cimalaka District of Sumedang, West Java, Indonesia have realized the importance of the animal disease and $77,8 \%$ of them knew the prevention. The majority of farmers $(61,1 \%)$ were experienced in recognizing the animal disease and $85,3 \%$ of them depend on individual experiences and conclusions without a basic guidance on recognizing diseases and procedures for developing dairy goats from books or other references. They used the conventional treatment such as tamarind solution for cough and cold or regular human medicine from the nearest stall, warm water compress or administer cooking oil orally for flatulence. The farmers thought that the options were the fastest and the most practical choices since they are reachable and affordable. However, the decision is very risky because trial and error of drug selection would affect the loss of farmer soon or later.

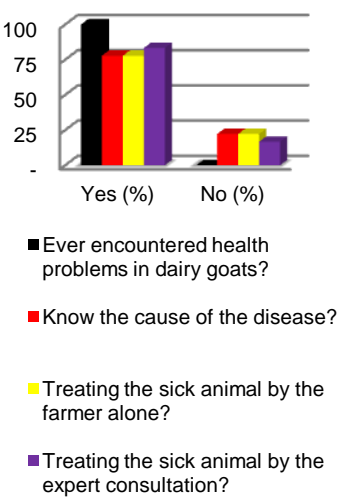

(A)

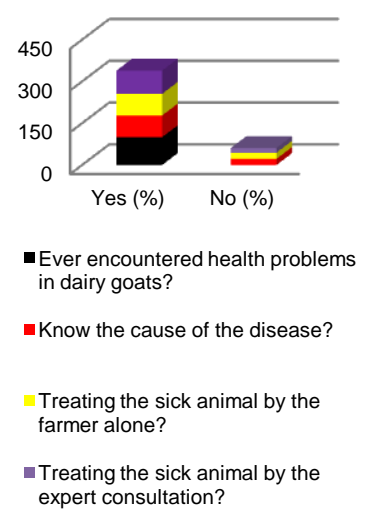

(B)
Figure 1. Basic knowledge about dairy goat health (A), farmers experience in directing health management of dairy goats (B)

All of the farmers mentioned that they have faced health problem in the animal but only $77,8 \%$ of them knew the cause of the disease. While $77,8 \%$ were assured to treat the sick goats alone, only $83.3 \%$ of farmers would contact veterinarian but the rest preferred to sell the animal in the market. In some time, the farmers were demanded in handling their sick dairy goats, since they realized that they are away from the vets. Other obstacles are economic problems, difficulties in finding appropriate drugs and limited knowledge of dairy goats' disease.

The limited number of veterinarians almost occurred in most regions in Indonesia as it is estimated consists of approximately 12.500 thousand people, while the profession needs to reach is 20 thousand people (Salasia, 2016). Besides that, most breeders in Indonesia are traditional farmers who make the farm as a side business or just a short-term investment. So it is possible that the farm runs without planning (Sardjito, 2017). It certainly will affect the financial ability of farmers. It would be reliable if the farmer decision in treating the animal is based on sufficient knowledge. Otherwise it would be better if the breeders have a higher awareness to consult a vet. Because of the high experience without sufficient medical knowledge is not enough to maintain animal health management.

\section{- CONCLUSION}

From the field observations, it can be concluded that the majority of dairy goat farmers in the village Cilengkrang Cimalaka District of Sumedang, have experienced and confidence to overcome certain diseases of dairy goats. Nevertheless, the knowledge and supported references are still limited, so the use of inappropriate traditional herbs or regular human medicines from nearby stalls is still relatively high. It is necessary to improve the awareness and knowledge of the farmers.

\section{- AUTHOR INFORMATION}

\section{Corresponding author}

*TH: tyagita.hartady@ gmail.com

Department of Basic Biomedical Science, Division of Anatomy, Physiology and Cellular Biology, Faculty of Medicine, Padjadjaran University, Indonesia.

\section{REFERENCES}

Haq IMN, Nurlina L, Alim S. 2016. Peran kepemimpinan ketua kelompok peternak kambing perah terhadap keberlanjutan usaha anggotanya. Students e-Journal 5(4): 1-11.

Salasia SIO. 2016. Indonesia Butuh 20 Ribu Dokter Hewan. http://www.republika.co.id/berita/nasional/umum/16/12/23/oiljj 8365-indonesia-butuh-20-ribu-dokter-hewan. Accessed on 13 Februari 2018.

Sardjito T. 2017. Peternakan bisa berkembang tapi.. http://news.unair.ac.id/2017/01/06/peternakan-bisa-berkembangtapi/. Accessed on 12 February 2018.

Widyastuti R, Winangun K, Wira DW, Ghozali M, Syamsunarno, MRAA. 2017. Tingkat pengetahuan dan pespon peternak kambing perah terhadap penyakit hewan (Studi Kasus: Kelompok Tani Simpay Tampomas Cimalaka Sumedang), Dharmakarya. 6(2): 89-92

Yunita D, Widyastuti R, Syamsunarno, MRAA, Rasad SD, and Indika DR. 2017. Pembagian peran dan pengambilan keputusan dalam rumah tangga peternak kambing perah di Desa Cilengkrang Kecamatan Cimalaka Kabupaten Sumedang, Jurnal Ilmu Ternak. 17(1): 21-26. 